\title{
The Use of "Monumen Perjuangan Rakyat Jawa Barat" Museum Collection as Social Studies Learning Resources
}

\author{
Linda Siti Zainab ${ }^{1}$, Murdiyah Winarti², Muhammad Iqbal ${ }^{3}$ \\ ${ }^{1}$ SMP IT Nurul Imam, Bandung, Indonesia \\ ${ }^{2,3}$ Social Studies Study Program, Faculty of Social Science Education \\ Universitas Pendidikan Indonesia, Bandung, Indonesia
}

\begin{abstract}
This research is arranged by seeing the reality in school that some of the resources used by teachers are limited with no any various resources to learn social studies subject in junior high school. This research is also done to describe the relevance of the museum that can be benefited as social studies resources. The approachment used for this research is qualitative and descriptive method implemented in Museum Monumen Perjuangan Rakyat Jawa Barat. Technique of collecting data used for this research is observation, interview, and documentation. Based on the findings of the research, the museum collection in Museum Monumen Perjuangan Rakyat Jawa Barat is relevance with social studies resources for junior high school. As for basic competence of social studies subject which in appropriate with the museum collection is the material on KD (Basic Competence) 3.4 and KD 4.4 class VII, VIII, and IX of junior high school. The values contained in the museum collection are value of struggle, nasionalism, braveness, caring, mutual cooperation, and value of patriotism. The use of this museum is for learning process of social studies which is using Project Based Learning model, for instance, the making of vlog is given to students to tell their observation result from the museum also the teacher could ask students to do self-reflection after visiting the museum.
\end{abstract}

Keywords: Museum, Values, Social Studies Resources

Correspondence.lindazainab56@gmail.com

Article History. Received January 2019, Received in revised March 2019, Accepted June 2019

O2019. International Journal Pedagogy of Social Studies. Department of Social Studies Education

\section{INTRODUCTION}

Museum is a place for introducing memorable and important events in the past to society. Government ordinance of Republic of Indonesia No. 66 year 2015 article 1 that, "Museum sebagai lembaga melaksanakan tugas di bidang pendidikan melalui pemanfaatan museum untuk kepentingan pendidikan" or, in short, museum is an institution which its duty is to utilise for education. In fact, people and some of civitas academica see museum only as a storage an a place for maintaining artefact or historical goods. Several schools only give social stuies subject via handbook or an activity in the classroom. In learning process, it needs learning resources to achieve the effectiveness. This research focuses on the use or the utilization of musem collection as learning resources especially for learning social studies in junior high school (Analysis of Social Studies Learning Resources in The Hindu-Buddhism Period, Islam, Before Independence, and After Independence). Then, the values gained from Museum Monumen Perjuangan Rakyat Jawa Barat are also analyzed to be used in learning process of social studies subject and to describe the way of using its museum collection as social studies resources.

Sanjaya (2010:175) mentrioned that learning resource is whatever can be used and utilised by the students to learn matter and learning experience in line with the aims wanted to achieve. According to AECT (Association of Education and Communication Technology), 


\section{LINDA ZAINAB, MURDIYAH WINARTI \& MUHAMMAD IQBAL/The Use of "Monumen}

Perjuangan Rakyat Jawa Barat” Museum Collection as Social Studies Learning Resources

there are six kinds of learning resources: message, person, matter, tool, technique, and environtment. One of them are museum as the environtment that can be used by students to learn social studies subject through its museum collection. According to Komalasari (2013:116), learning resource can be categorized as two: reading material and nonreading material. In this research, museaum is one of non-reading material. It means the material is can be seen (visual) and can be heard (audio) to explain the message or intention from interpretations in the form of words printed as books. Something has a value if it can be used and utilised well, so does with the value from the museum.

Programme of social studies education, according to Sapriya (2012:48) included four dimensions: knowledge, skill, value and attitude., also action. Based on the statement, social studies education has value. So, it is important to learn value through Museum Monumen Perjuangan Rakyat Jawa Barat. Another opinion from Ranjabar (2006:109), "nilai itu adalah gabungan semua unsur kebudayaan yang dianggap baik/buruk dalam suatu masyarakat", so that is why people in the society had to comprehend fully and apply the value which is admitted as the ideal ones.

Value can be learned through the process of learning social studies. According to National Council for the Sosial Studies (NCSS) as a professional organization build with the aim to develope social studies in 1921, reveals the definition of social studies (1993) quoted in Sapriya (2007:3) that:

Social studies is the integrated study of the social sciences and humanities to promote civic competent. Within the school program social studies provide coordinated systematic study drawing upon such disciplines as anthropology, archeology, economic, geography, history, law, philosophy, political science, psychology, religion, an sociology, as well as appropriate content from the humanities, mathematics and natural sciences. The primary purpose if social studies is to help young people develop ability to make informed and reasoned decision for the public good as citizen of a culturally diverse, democratic society in interdependent world.

Based on the above opinion, social studies is the combination of some social knowledges (anthropology, archaeology, economics, geography, history, law, philosopy, sociology, and so on) which inside these social knowledges can be found concepts of social studies that has the aim to create or make good citizen. Pratiwi (2019) stated that, "Social studies learning in the 2013 curriculum aims to for citizens who have knowledge and understanding of the environment and society". So, according to curriculum 2013, learning social studies will give citizen knowledge and the understanding of environment of the society.

\section{METHOD}

Methodology is the most important part in every research because it includes some aspects towards way or tactics as steps to be done by a researcher to solve at least a problem to achive an aim. This research uses descriptive qualitative method to collect data or source. Considering the problems that will be analyzed and the research which need a deep observation, so, the researcher uses qualitative approachment. The researcher tries to identify collection in the museum that can be used or utilised as learning resource. According to Bogdan and Taylor in Moleong (2010:4), they explains taht qualitative research is a procedure of research to deliver descriptive data in the form of written or spoken words from people or behavior that can be analyzed. Then, according to Djam'an (2011:23) states that qualitative research is done because the researcher wants to explore phenomenon which can not be made as the quantitative one or it must be done in the 
result of description of the collection in that museum.

According to Sukmadinata (2011:73), descriptive qualitative research is aimed to describe and imagined the phenomenon, whetever it is natural or not, with the concerning towards characteristics, quality, and the relation between the events involved. Other than the descriptive research does not give the change or manipulation to the variable used for the research, but it will draw the real condition.

This research is located in the Museum Monumen Perjuangan Rakyat Jawa Barat, Dipati Ukur Street No. 48 Bandung. This museum is chosen because the researcher wants to identify the relevance collection in the museum to be learning social studies resources in junior high school towards the material of Hindu-Buddhism Period, Islam, Before Independence, and After Independence.

According to Sugiyono (2013:308), technique of collecting data is a prominent step in the research because the aim of this research is to gain the data. Technique of collecting data used in this research are observation, structural interview, and documentation. Then, validity of the data is needed a way to fullfill the chriteria of credibility: to lengthen the observation time and triangulation In this research, triangulation is done via technique collecting data: interview, observation, and documentation.

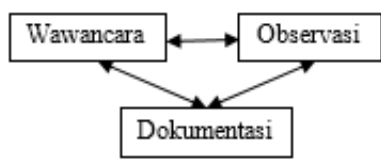

Picture 1. Triangulation with Three Collecting Data

Source: Sugiyono (2012:26)

One of qualitative research features are the researcher is behaved as the instrument also as the data collector. Research instrument, according to Sugiyono (2013:148) stats that, "suatu alat yang digunakan mengukur fenomena alam maupun sosial yang diamati". In short, an instrument is used to measured natural or social phenomenon. Research procedure is done by using three steps. The first one is called preresearch to identify problems and licence of the location or place that will be used. Second, the implementation step to start the research which is guided by the instrument chosen before (triangulation: interview, observation, and documentation). The last one is technique of analyzing data.

In this research, technique of analyzing data used are, first, the reduction of the data. it is to enclose and choose the main things and focus to the important matter, to find pattern and theme. Next is to serve the data. it is started by doing the process of collecting data via observation, interview, and socumentation. In qualitative research, serving the data can be done in the form of short analysis or draft, chart, relation between the category, flowchart and so forth (Sugiyono, 2009:95) and the last is conclusion drawing or verification.

Conclusion drawing or verification is the way to make conclusion and verification from the first data gained. Conclusion in qualitatice research making is a new finding that have never been used. Findings can be in the form of description or imagination/drawing of an object so that it will make clearer after being analyzed. It can be a causal relation or interactive (Sugiyono, 2009:99)

\section{RESULTS AND DISCUSSION}

The researcher will explain the findings of this research towards the use of collection in Museum Monumen Perjuangan Rakyat Jawa Barat as social studies resources (Analysis of Social Studies Learning Resources in The Hindu-Buddhism Period, Islam, Before Independence, and After Independence). The findings is the result of collecting data that is arranged, based on the research questions chosen. There are three things that will be explained. The first one is the relevance 
collection in the Museum Monumen Perjuangan Rakyat Jawa Barat with the socil studies resources. Second is description towards value can be gained by visiting collection in the Museum Monumen Perjuangan Rakyat Jawa Barat, and the last is the way of utilizing the collection of Museum Monumen Perjuangan Rakyat Jawa Barat as social studies resources.

Table 1. List of The Most Near Junior High School with Museum Monumen Perjuangan Rakyat Jawa Barat

\begin{tabular}{|c|c|c|}
\hline No & School & $\begin{array}{c}\text { Distance to } \\
\text { Museum }\end{array}$ \\
\hline 1 & SMP PGII 1 & $600 \mathrm{~m}$ \\
\hline 2 & SMP PGRI 6 & $1,1 \mathrm{~km}$ \\
\hline 3 & $\begin{array}{l}\text { SMP Al-Falah Dago } \\
\text { Bandung }\end{array}$ & $1,7 \mathrm{~km}$ \\
\hline 4 & $\begin{array}{ll}\text { SMP } & \text { Kemah } \\
\text { Indonesia } 4 & \end{array}$ & $2,3 \mathrm{~km}$ \\
\hline 5 & SMP Pertiwi & $2,3 \mathrm{~km}$ \\
\hline 6 & SMP Nasional & $2,5 \mathrm{~km}$ \\
\hline 7 & $\begin{array}{l}\text { SMP Negeri } 7 \\
\text { Bandung }\end{array}$ & $3,0 \mathrm{~km}$ \\
\hline 8 & $\begin{array}{l}\text { SMP Negeri } 44 \\
\text { Bandung }\end{array}$ & $3,1 \mathrm{~km}$ \\
\hline 9 & $\begin{array}{l}\text { SMP Edu Global } \\
\text { School }\end{array}$ & $3,2 \mathrm{~km}$ \\
\hline 10 & SMP Istiqamah & $3,7 \mathrm{~km}$ \\
\hline
\end{tabular}

This research is specifically for students of junior high school that learn social studies subject. According to the above table, the location of Museum Monumen Perjuangan Rakyat Jawa Barat is near with some of junior high school there. The most near school to the museum is SMP PGII 1. So, the researcher chooses Museum Monumen Perjuangan Rakyat Jawa Barat as the targeted location for this research to know the use of Museum Monumen Perjuangan Rakyat Jawa Barat as social studies resources for all grade of junior high school resources (Analysis of Social Studies Learning Resources in The Hindu-Buddhism Period, Islam, Before Independence, and After
Independence). From several schools, the researcher does the observation and interview towards some students and teacher of social studies subject in two schools: SMP PGII 1 and SMP PGRI 6 .

Picture 2. Monument of Perjuangan Rakyat

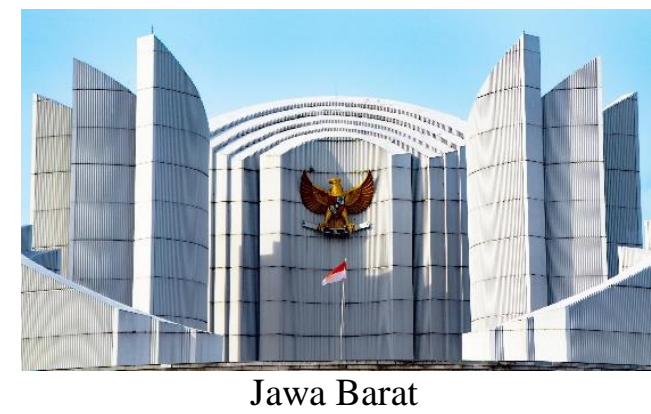

Monument of Perjuangan Rakyat Jawa Barat was built as a form of appreciation for the commendable service from the heroes, especially the heroes who came from West Java as a means of the next generation in the nation. The monument is shaped in sipky bamboo combined with modern architectural style which was designed by the original architect of Bandung, Mr. Slamet Wirosanjaya and Sunaryo. The location of the construction of this museum was set on January 28th 19982 and was inaugurated by the Governor of West Java at that time, Mr. Mayjen R. Nuriana on August 23rd 1995.

The mapping of collection in Museum Monumen Perjuangan Rakyat Jawa Barat are relevant to social studies resources. One of the examples is diorama. Diorama is threedimensional views in small size to demonstrate or explain a situation or phenomenon that supports the activity. This museum has nine dioramas displayed: the battle of Sultan Ageng Tirtayasa who defended Sultanate of Banten in 1862 , people's participation in the constuction of roads in Sumedang, Sakola Kautamaan Istri 1914 (The School of Women), Palagan Bojong Kokosan on December 9th 1945, Bandung Lautan Api on March 24th 1946, Linggarjati negotiations in 1946, Long March Siliwangi, 
Asian-African Conference in Bandung on 1955, and the last one is Operasi Pagar Betis (Bharatayudha) in 1962. These dioramas is relevant with social studies resources so that it can be used and utilised. As for the suitability of basic competences in social studies subjectin junior high school with dioramas as the collections of Museum Monymen Perjuangan Rakyat Jawa Barat, those are KD 3.4 and KD 4.4 in grade VII, VIII, and IX of junior high school

Picture 3. Diorama of Bandung Lautan Api

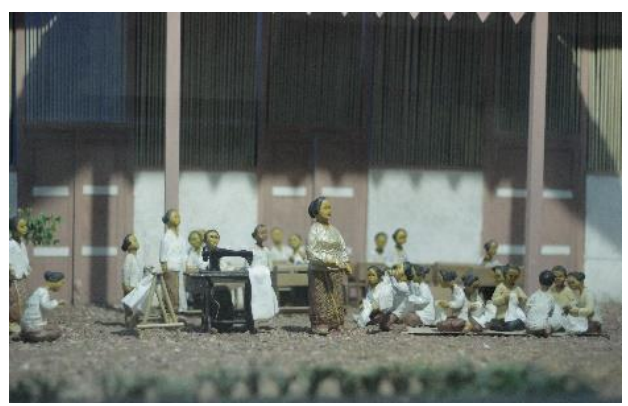

Bandung Lautan Api incident occured in 1946 as the physical struggle to defend the independence of the Republic of Indonesia. In the relation to social studies resources, the diorama above is relevant to social studies subject in the class IX namely KD 3.4 "Menganalisis kronologi, perubahan dan kesinambungan ruang (geografis, politik, ekonomi, pendidikan, sosial, budaya) dari awal kemerdekaan sampai awal reformasi" and 4.4 "menyajikan hasil analisis kronologi, perubahan dan kesinambungan ruang (geografis, politik, ekonomi, pendidikan, sosial, budaya) dari awal kemerdekaan sampai awal reformasi" exactly in the class IX mterial chapter IV "Indonesia dari Masa kemerdekaan Hingga Masa Reformasi" Sub Bab A "Masa Kemerdekaan (1945-1950)" at the third point, "Perjuangan Mempertahankan Kemerdekaan".

If it is seen from social side, people there worked together to expel the invaders. Students can take the message or lessons and wisdom contained in Bandung Lautan Api incident, the teachers can invite or ask their students to reflect on the events that have occured so that it can be applied in their daily life.

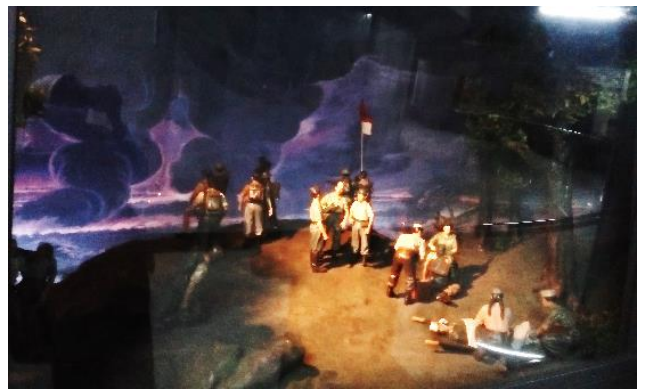

Picture 4. Diorama of Sakola Kautamaan Istri

R. Dewi Sartika is the founder of Sakola Kautamaan Istri or school for women. The illustration can be seen from the diorama above that it imagines the condition of a school with some activities. The school was built because the awareness of R. Dewi Sartika towards women in the early 19th century. Women were seen lower than men, especially in education. Based on the condition, R. Dewi Sartika has a great desire towards the developement of women. In that school, a daughter gain general knowledge also another lessons to dig their own skill as cooking, making batik, sewing, crocheting, embroidering, and so forth. In this school, women were also taught religion which in other schools were forbidden.

The effort of R. Dewi Sartika to develope education for women is revelant with the material in social studies subject KD 3.4 "Menganalisis ruang (geografis, politik, ekonomi, pendidikan, sosial, budaya) dari masa penjajahan sampai tumbuhnya semangat kebangsaan" and basic competences or KD 4.4 "menyajikan kronologi perubahan dan kesinambungan ruang (geografis, politik, ekonomi, pendidikan, sosial, budaya) dari masa penjajahan sampai tumbuhnya semangat kebangsaan" with the material for grade VII of junior high school in chapter IV "Perubahan Masyarakat Indonesia pada Masa Penjajahan dan Tumbuhnya Semangat Kebangsaan" second semester in sub-chapter C "Tumbuh dan Berkembangnya Semangat Kebangsaan".

The museum of Monumen Perjuangan Rakyat Jawa Barat is enriched by the values that can be learned and emulated from West Java 


\section{LINDA ZAINAB, MURDIYAH WINARTI \& MUHAMMAD IQBAL/The Use of "Monumen}

Perjuangan Rakyat Jawa Barat” Museum Collection as Social Studies Learning Resources

warrior figures or from the past events for social studies subject in junior high school. The researcher found values contained in the museum. For instance, it can be seen from the diorama of Sakola Kautamaan Istri, there can be found the value of struggling, the value of good model, and the value of caring that was shown by R. Dewi Sartika. The relief of Indonesia Menggoegat which Soekarno speech to defend from colonialism. The value shown by the relief is the value of braveness to struggle or put the unending effort for the nation. The diorama of Palagan Bojong Kokosan is an heroic action from the warriors in West Java to catch the enemy. Here, the value that students can gain are the value of struggling and braveness. So does

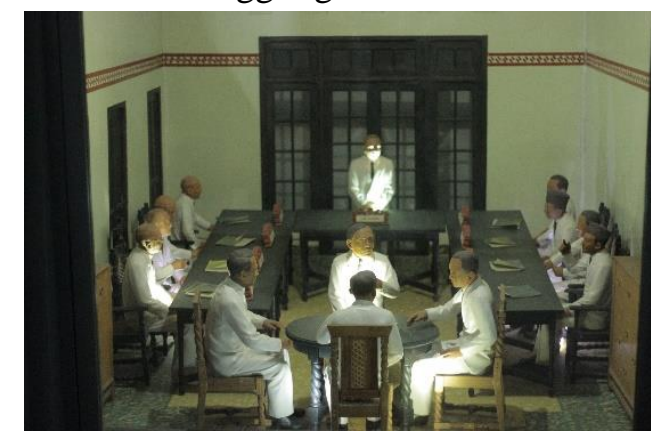

with the diorama of Asian-African Conference.

Picture 5. The Diorama of Linggarjati

Negotiations

The diorama above is illustrated the diplomacy struggle done by the Indonesian government to defend our nation in the independence. Indonesia shows good determination or conviction in solving the dispute with Netherland. This Linggarjati Negitiations was done in Linggarjati, Kuningan, West Java Province on November 10th 1946. This negotiations decided some agreements which were signed officially by both nation in March 25th 1947. Sutan Syahrir was the delegation from Indonesia and Wim Schermerhorn is the chief of delegation from Netherland, while Lord Killearn as the mediator of the negotiations.

The result of this negotiations was harmful for Indonesia. the result were: Netherland admitted Indonesia by de facto only for some regions as like Sumatra, Java, and Madura. Then, Netherland must leave the region of Indonesia lately in January 1st 1949; Republic of Indonesia and Netherland decided to built RIS or Republic of Indonesia Union in which Indonesia, in the form of RIS had to join the Indonesia-Dutch commonwealth with the Dutch Queen as its chairman. As for the impact of it, Indonesia finally received recognition from several countries, such as Britain, US, Egypt, Lebanon, Syria, Afghanistan, Myanmar, Yemen, Saudi Arabia, and Soviet Union. Thus, it was still got some rejection among Indonesian people because some of them considered that this result was very detrimental for Indonesia.

This negotioations in Linggarjati is illustrated in the diorama and cam be used as social studies resources. This material is there in the class IX, exactly in second semester. It can be seen in KD 3.4, "Menganalisis kronologi, perubahan dan kesinambungan ruang (geografis, politik, ekonomi, pendidikan, sosial, budaya) dari awal kemerdekaan sampai awal reformasi" and KD 4.4 "menyajikan hasil analisis kronologi, perubahan dan kesinambungan ruang (geografis, politik, ekonomi, pendidikan, sosial, budaya) dari awal kemerdekaan sampai awal reformasi" with Sub-chapter A "Masa Kemerdekaan" , third point of "Perjuangan Mempertahankan Kemerdekaan" as the diplomacy struggle.

The researcher can be enclosed that the values contained in musem collection in Museum Monumen Perjuangan Rakyat Jawa Barat are: the value of struggling, the value of nasionalism, value of the good model as warrior, value of working together, value of useful for others, value of caring, and the value of braveness. Museum Monumen Perjuangan Rakyat Jawa Barat gives the message towards the urgency of being useful for others or for the surroundings because all the heroics events and commendable service from the late of the warriors to defend every meters of the nation so 
that the values from Museum Monumen Perjuangan Rakyat Jawa Barat can be used for social studies resources.

All the collections in Museum Monumen Perjuangan Rakyat Jawa Barat can be used for social studies resources of junior high school, especially for learning history in The HinduBuddhism Period, Islam, Before Independence, and After Independence. The use of it can increase knowledge and experience of the students. It can be applied Project Based Learning model by doing some steps: giving the understanding, guiding also stimulous to students who visit the museum so that students can explore social studies material more and more and their idea also will develope. Thus, teachers also can give the students some assignments to observe some museum collections there or some group assignment to describe some of museum collections to be recorded and uploaded to their own social media and ended by making the presentation or discussion in the class based on their observation in the museum of Monumen Perjuangan Rakyat Jawa Barat.

\section{CONCLUSION}

Based on the findings data from the research of the use of museum collection in the museum of Monumen Perjuangan Rakyat Jawa Barat as social studies resources in The HinduBuddhism Period, Islam, Before Independence, and After Independence, this museum can be used and utilised also relevant with the material of social studies. Some of mapping of museum collections are started by relief, diorama, and another artefact or historical goods that has the relation with the material so that teachers must give the stimulous to the students to explore more knowledge and experience inside the museum of Monumen Perjuangan Rakyat Jawa Barat.

Everything, actually has the value, so does with the museum of Monumen Perjuangan
Rakyat Jawa Barat. Those are: the value of struggling, the value of nasionalism, value of the good model as warrior, value of working together, value of useful for others, value of caring, the value of braveness, and so on. So, it can be concluded that musem collection in the museum of Monumen Perjuangan Rakyat Jawa Barat can be used as social studies resources via Project Based Learning model.

\section{REFERENCES}

Djam'an, Satori \& Komariah, Aan. (2011). Mitologi Penelitian Kualitatif. Bandung: Alfabeta.

Komalasari, Kokom. (2013). Pembelajaran Kontekstual: Konsep dan Aplikasi. Bandung: PT. Refika Aditama.

Moleong, LJ. (2010). Metodologi Penelitian Kualitatif. Bandung: Remaja Rosdakarya. Peraturan Perundang-undangan Indonesia.

Pratiwi, Galuh Candra. (2019). Utilization of Internet Content as A Learning Source of IPS in SMP Negeri 9 Bandung. Internasional Journal Pedagogy of Social Studies. Volume 4, No. 1, 9-16. [Online]. Tersedia di: http://dx.doi.org/10.17509/ijposs.v4i1.15 $\underline{382}$.

Ranjabar, Jacobus. (2006). Sistem Sosial Budaya Indonesia: Suatu Pengantar. Bogor: PT. Ghalia Indonesia.

Sanjaya, Wina. (2010). Strategi Pembelajaran Berorientasi Standar Proses Pendidikan. Jakarta: Prenada Media.

Sapriya. (2007). Konsep Dasar IPS. Bandung: UPIpress.

Sapriya. (2012). Pendidikan IPS, Konsep dan Pembelajaran. Bandung: Rosdakarya.

Sugiyono, (2013). Memahami Penelitian Kualitatif. Bandung: Alfabeta.

Sukmadinata, Nana Syaodih. (2011). Metode Penelitian Pendidikan. Bandung: PT Remaja Rosdakarya. 